\title{
Агаева И.Б., Куник М.А. \\ Теоретическое изучение сформированности речи у старших дошкольников с расстройством аутистического спектра и общим недоразвитием речи II уровня
}

ФГБОУ ВО «Красноярский государственный педагогический университет имени В.П.Астафьева

(Россия, Красноярск)

doi: $10.18411 / s r-10-04-2021-37$

\section{Аннотация}

В статье представлен теоретический анализ сформированности речи у детей 5-6 лет с расстройством аутистического спектра и общим нарушением речи второго уровня, выявлены особенности, которые позволяют сформировать коррекционные программы для этих нарушений.

Ключевые слова: расстройство аутистического спектра, общее недоразвитие речи II уровня, старший дошкольный возраст, развитие речи, коммуникативные умения, логопедическая программа.

В последнее десятилетие в педагогической науке все чаще говорят о расстройствах аутистического спектра (далее РАС), что свидетельствует о неуклонном росте количества детей с данным психическим нарушением.

О.С. Никольская, М.М. Либлинг и Е.Р.Баенская считают, что в качестве ведущего признака РАС у старших дошкольников выступает несформированность коммуникативных навыков. Эти дети практически не испытывают потребности в общении, автономны, эгоцентричны и оторваны от реальности. В их активном словаре отсутствуют слова, обозначающие близких людей [5].

Одним из важнейших проявлений расстройство аутистического спектра у старших дошкольников являются нарушения речи. В первую очередь расстройства речи влияют на коммуникативную функцию, т.е. ребенок не использует речь для социализации с окружающей средой [2]. Таким детям сложно обратиться к другому человеку, выразить свои нужды или попросить о чём-либо, при этом они могут рассеяно повторять слова, которые их заинтересовали. Часто у дошкольников возникают трудности в невербальном общении, например с помощью жестов рук, зрительного контакта.

Для детей с РАС обучение коммуникативным навыкам имеет важное значение для раскрытия своего потенциала. Коррекционная работа с дошкольниками должна начинаться как можно раньше через разработку адекватной программы, учитывающей специфику ребенка, его личностные особенности, коммуникативные возможности $[1,3]$. Важно регулярно подкреплять позитивные результаты. Большинство старших дошкольников хорошо реагируют на высокоструктурированные специализированные программы. Родители и другие члены семьи должны быть вовлечены в программу коррекционной работы с ребенком, которая должна стать частью его повседневной жизни.

В отличие от детей с РАС, старшие дошкольники с общим недоразвитием речи (далее ОНР) II уровня имеют иные особенности. Существенным является факт наличия общеупотребительной речи в сравнении с дошкольниками с РАС. Старшие дошкольники с ОНР II уровня говорят с ошибками, у них страдают звукопроизносительные умения, но имеет место грамматическая связь между словами.

Словарный запас дошкольников с ОНР ІІ уровня достаточно скудный, требуется его расширение с использованием специальных коррекционных логопедических программ [3]. Разработка и реализация логопедических программ должна быть нацелена на устранение недостатков речевого развития старших дошкольников с ОНР II уровня, а именно решать задачи: 
- обогащения и расширения словаря;

- нормативного употребления лексики;

- объединения слов с учетом их групповой принадлежности и др.

Особое значение в логопедической работе со старшими дошкольниками с ОНР II уровня следует уделять правильному звукопроизношению. Данный контингент дошкольников склонен заменять одни звуки другими, искажать звуки и т.д. Специалисты, работающие с детьми с ОНР II уровня, отмечают тот факт, что говорить такие дети начинают значительно позже своих сверстников и их речь на бытовом уровне относительно сохранна, но при этом старшие дошкольники активно продолжают пользоваться жестикуляций, которая облегчает словесное выражение мысли.

Таким образом, теоретический сравнительный обзор сформированности речи у старших дошкольников с РАС и ОНР II уровня выдвигает необходимость организации адекватной коррекционно-логопедической работы по преодолению коммуникативных трудностей у рассматриваемой группы дошкольников, с целью их дальнейшей социализации и адаптации в социум.

$$
* * *
$$

1. Агаева И.Б. Коррекционно-педагогические подходы к развитию речи детей с задержанным речевым развитием // Современные технологии коррекционно-развивающей работы с детьми, имеющими ОВ3. Красноярск, 2019.- 3 с.

2. Волковская Т.Н., Юсупова Г.Х. Психологическая помощь дошкольникам с общим недоразвитием речи. М.: НКЦ, 2014. - 96 с.

3. Детский аутизм. Хрестоматия. / Сост. Л.М. Шипицына. СПб., 1997. -239 с.

4. Мамаева А.В. Протоколы логопедического обследования дошкольников: методические рекомендации. Красноярск,2019. -55 с.

5. Никольская 0.С, Аутичный ребенок, пути помощи / О.С. Никольская, Е.Р. Баенская, М.М. Либлинг. М.: Теревинф, 1997. -226 с.

\section{Балтрашевич В.Э. \\ Разработка АОС программного блока вывода}

Санкт-Петербургский Государственный электротехнический университет (Россия, Санкт-Петербург)

doi: $10.18411 / s r-10-04-2021-38$

\section{Аннотация}

Рассматривается пример разработки автоматизированной обучающей системы (AOC) программного блока логического вывода экспертной системы. Блок вывода описан на языке эксперта, использующего правила продукций. АОС же строится на базе списка атрибутов без использования правил продукции. Таким образом, при разработке использовались две базы знаний с разными структурами. Приводится пример использования АОС.

Ключевые слова: Поверхностные и глубинные знания эксперта, контроль знаний обучаемого, логический вывод, представление графа

\section{Abstract}

An example of the development of an automated training system (ATS) of a program block of logical inference of an expert system is considered. The inference block is described in the language of an expert using production rules. AOC, on the other hand, is based on a list of attributes without using production rules. Thus, during the development, two knowledge bases with different structures were used. An example of using AOC is given.

Keywords: Surface and depth knowledge of the expert, knowledge control of the trainee, logical conclusion, graph representation 